\title{
Designing and Implementing Curriculum for Students With Special Needs: A Case Study of a Thinking Curriculum
}

\author{
Tas Adam \\ Victoria University, Australia \\ Anna Rigoni \\ Concord School, Australia \\ Arthur Tatnall \\ Victoria University, Australia
}

\begin{abstract}
Over the years, ICT has emerged as a platform that is seen to enhance the knowledge and skills of students in mainstream learning environments. A growing number of schools however, now provide a separate alternative enrolment for students with special needs. Although there are valid opinions on what is the best method of educating these students (integration vs. segregation) it has been noted by many researchers that technology can play a major role in the learning process. In this paper, an e-learning paradigm is applied in a holistic manner to a special learning community with the aim of determining an appropriate e-learning model and platform to support curriculum design. The paper focuses on a pilot project at a suburban school for students with special needs. The aims of the project are to observe the level of immersion and engagement and its impact on curriculum outcomes of the group. This research project further investigates the transition issues and approaches for this group and the links and relationships beyond the normal school environment. The project has been funded by the School of Information Systems and the School Community.
\end{abstract}

\section{Introduction}

It has been established by many studies that a link exists between technology and learning and that technology has played an important role in learning for many people (Torgesen and Young 1983; Dempsey 1993; Quinn 1996; Pillay 2000). These studies also show that over the last twenty years technology has also played a significant role in work with specific disadvantaged groups such as the blind and those with movement disabilities in the provision of media to facilitate communication and education (Poon and Head 1985). This paper will outline a research project that is investigating present

Copyright (C) 2006 Victoria University. This document has been published as part of the Journal of Business Systems, Governance and Ethics in both online and print formats. Educational and non-profit institutions are granted a nonexclusive licence to utilise this document in whole or in part for personal or classroom use without fee, provided that correct attribution and citation are made and this copyright statement is reproduced. Any other usage is prohibited without the express permission of the polices and their application to the use of information and communications technologies (ICT) to enhance the learning of the virtual community of students with learning disabilities.

There is a growing dilemma about school membership for students with learning disabilities (LD). Literature from the Australian Bureau of Statistics (ABS 1996; ABS 1997) and MCEETYA (1997) 
indicates that the prevalence of LD is approximately $10-15 \%$ at the primary levels, and is still significant at the secondary level at 5-10\%. Figures for Australia follow similar trends to those from the USA and other countries (NJCLD 1994).

A number of researchers including Bulgren (1998) and Agran (1977) support the view that students with learning disabilities require an alternative approach to their learning, while others claim that it is best to integrate these students with mainstream classes. Numerous integration and remedial programs have proved inefficient towards the total learning of this group of students (Adam and Tatnall 2002), and the literature shows that in some selected fields, for example in maths and social studies, specialist instruction has been applied to this group of individuals with little success (Johnson, Gersten and Carmine 1998; Klinger 1998; Swanson 1999). Overall however, there is strong evidence to support the existence of separate schools for students with special needs (Adam and Tatnall 2003). These schools exist on small funding support from the government and try to cater for individual differences in a significant way. This paper will refer to these students with special needs under the generic term learning disabilities and argues that use of the Internet and related technologies can make a significant difference to the education of these students.

\section{Educating Students with Learning Disabilities}

The definition of learning disabilities is still a little vague (Keogh and Speece 1996), and although LD research continues to grow and to have a significant impact on special education its classification remains problematic due to the vagaries and antagonisms surrounding the definition (Mather and Roberts 1994). At present two definitions are well supported: a legislative definition from the United States found in the 'Individuals with Disabilities Education Act' (IDEA 1997) and one proposed by the National Joint Committee on Learning Disabilities (NJCLD 1994), a consortium of representatives from organisations interested in LD.

In outline these definitions point out that a learning disability refers to a retardation, disorder, or delayed development in one or more of the processes of speech, language, reading, writing, arithmetic, or other school subjects resulting from a psychological handicap caused by a possible cerebral dysfunction and/or emotional or behavioural disturbances. It is not the result of mental retardation, sensory deprivation, or cultural and instructional factors (Kirk 1962). Specific Learning Disabilities is a chronic condition of presumed neurological origin which selectively interferes with the development, integration, and/or demonstration of verbal and/or nonverbal abilities. Specific Learning Disability exists as a distinct handicapping condition and varies in its manifestations and degree of severity. Throughout life, the condition can affect self-esteem, education, vocation, socialisation, and /or daily living activities (ACLD 1986 :15). Many previous studies on LD have focused on only one or two specific factors such as IQ, but the literature shows that a factor such as IQ does not yield valid results or assessments in regard to LD (Detterman and Thompson 1997). The literature also provides examples of where these students in normal classroom settings achieve little success in situations where technology was not regarded as an integral part of the curriculum (Zammit, Meiers and Frigo 1999).

The role of ICT can be easily realised now as the Victorian government has placed strong emphasis on its importance and availability. At a seminar in 2005, Victorian Government Minister, Marsha Thompson, reiterated a major policy to support schools in Victoria in various ways so that students would enhance their learning and employability position prospects. The policy has been also extended to Federal Government level, and tertiary institutions are seeking ways to incorporate ICT to improve graduate outcomes for these students (Adam, Rigoni and Tatnall 2005).

\section{Teaching/Learning Paradigms}

An important element in this study is a Learning Interface Model. The authors have examined earlier models, like the one shown in Figure 1 below, but have since adopted rather more sophisticated models. 


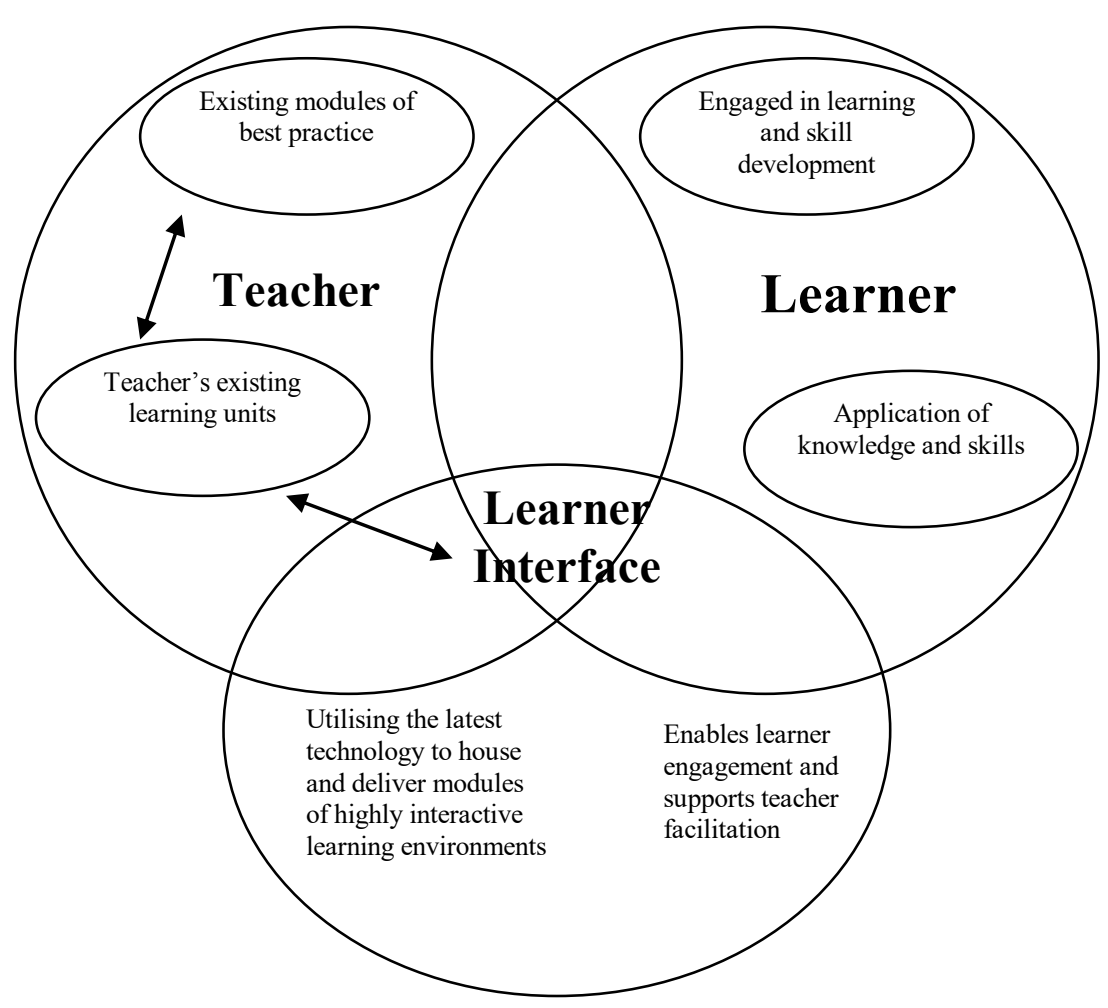

Figure 1: Learner Interface Framework

Teaching can be thought of as an interaction between teachers, students, experience and knowledge (Schunck and Nielsson 2001), and the way that these entities interact can be seen in different teaching/learning paradigms. Schunck and Nielsson (2001) outline three different stages in the development of current educational thinking, particularly as related to the use of technology in education. The first paradigm (Figure 2) is that of the verbal tradition (what Schunck and Nielsson call the paradigm of the past), which is characterised by a verbal flow of information streaming from the teacher directly to the students.

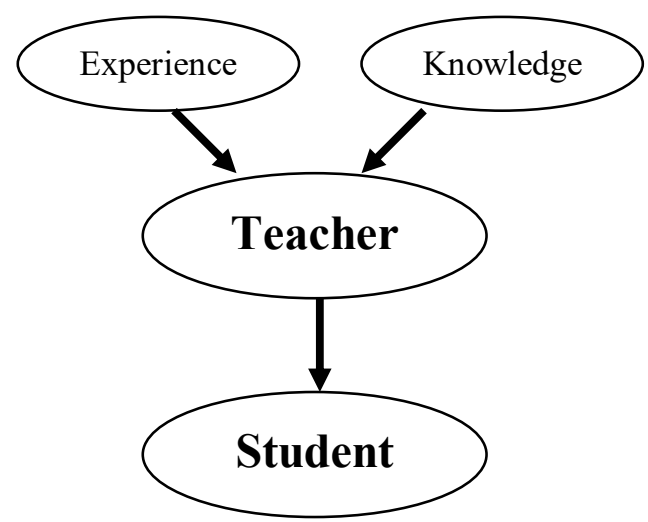

Figure 2: Paradigm of the verbal tradition

In the second paradigm (Figure 3), what they call the paradigm of today, communication is two way and students also communicate amongst themselves, but the teacher is really still at the centre. It is a paradigm where both teacher and student share responsibility, but the teacher remains the main source of information. 


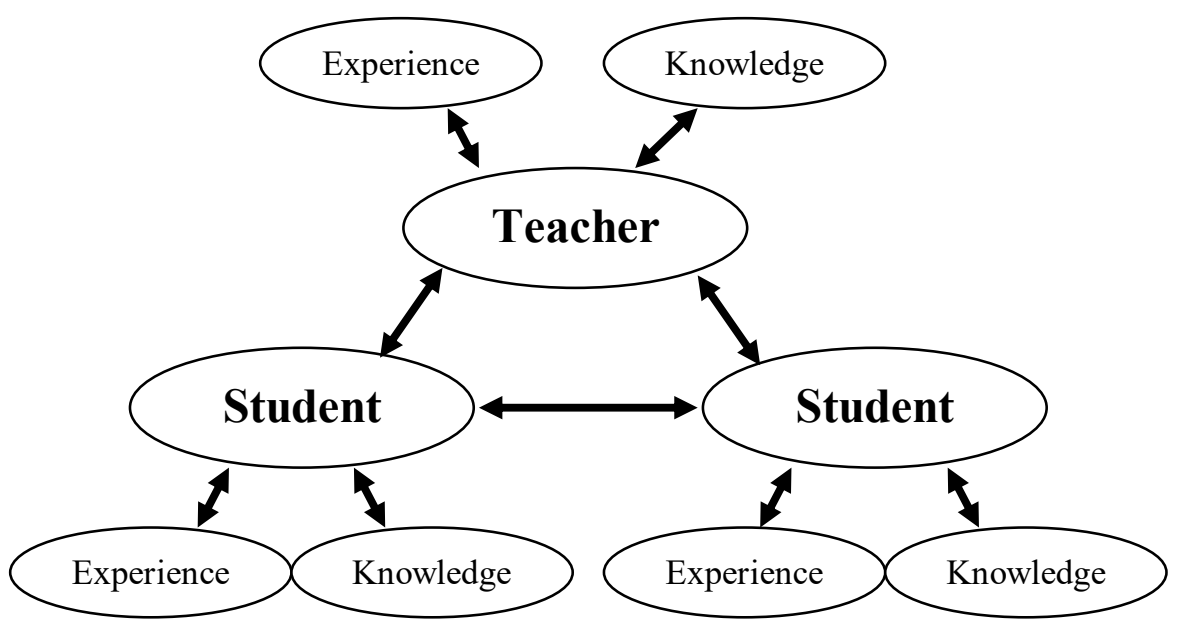

Figure 3: Paradigm of the teacher-centred classroom

The third paradigm (Figure 4) - the paradigm of tomorrow, differs in placing a knowledge base at the centre and giving both students and teachers important roles. Here, the teacher acts as a catalyst or consultant for students on where information can be obtained. The teacher also communicates their own knowledge and experience to the students, but this fills a smaller part of the interactions than before. This can really be considered as an e-learning paradigm where students make extensive use of technologies such as the World Wide Web to obtain information and experiences. With this teaching/learning paradigm the synchronous presence of both student and teacher is no longer necessary. The learning responsibilities of the students here are for 'searching', rather than 'receiving' as with earlier paradigms.

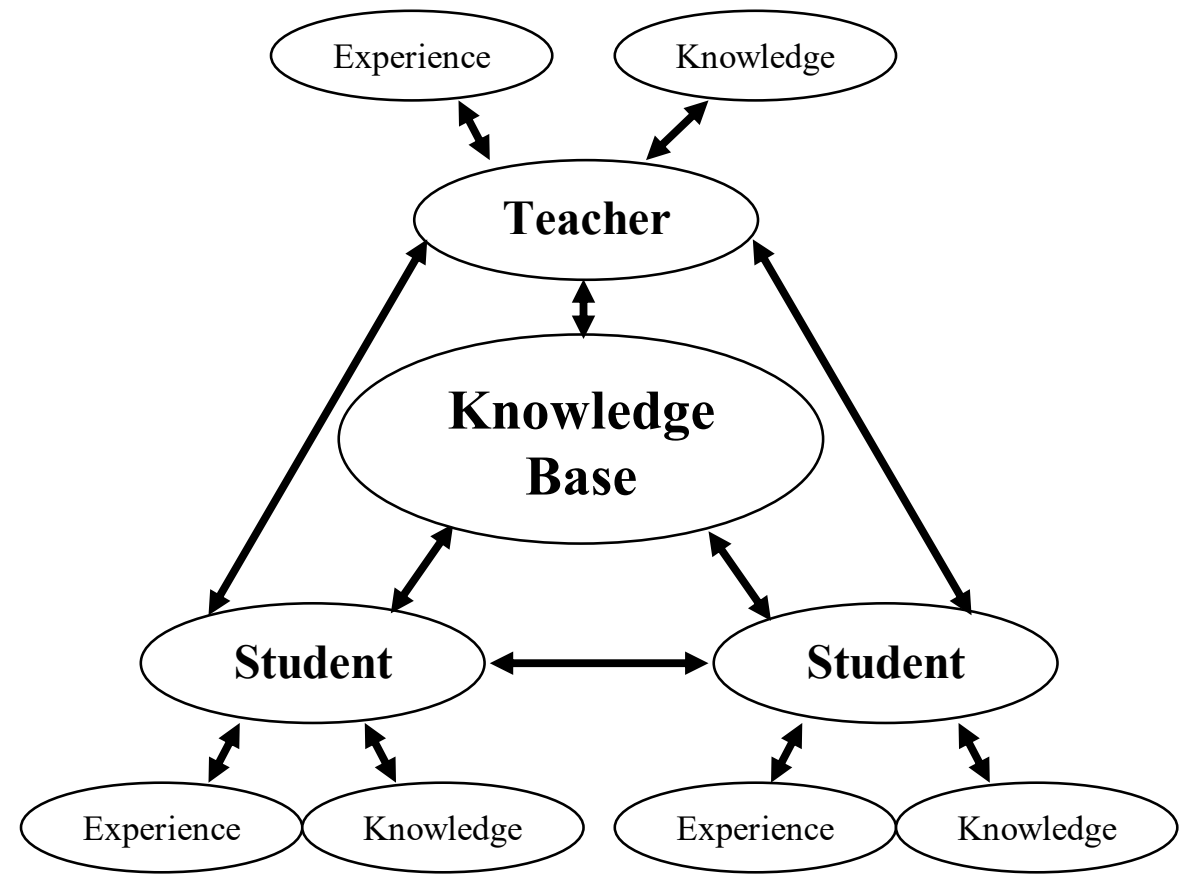

Figure 4: The e-learning paradigm

\section{Learning with ICT - Teaching Models}

A variety of teaching models are used with LD students. Agran (1977) describes a specific self instructional skills model for persons with mental retardation, and Bulgren (1998) used concept-based teaching routines to enhance the performance of LD students in secondary-level mainstream classes. Other studies used an individualised approach to enhance behavioural and special skills like maths, 
history and familiarity with money (for example Fernell (1996), Browder and Yan (1998), Bulgren (1998), Van-Luit and Naglieri (1999)). The literature also describes studies on adolescents with LD (Dillon 1985; Deshler and Ellis 1996). Studies specific to individual reading and natural language include those of Kircaali-Iftar, Birkan and Uysal (1998), Johnson et al. (1998) and Swanson (1999). In general, these studies relate to mainstream classroom teaching and management strategies (McIntosh 1993). Wang, Reynolds and Walberg (1987) describe the theoretical approaches to the education of mildly handicapped children as follows: the Psychological Approach, the Sensory-Neurological Approach, the Ecological Approach, and the Behavioural Approach (Morrison, Macmillan and Kavale 1985).

Fuchs (1996) provides a more recent analysis of models of classroom instruction which relate to students with learning difficulties. Mercer and Mercer (1981) support the view that LD students should be provided with individualised programming. This relies on the social constructivist-transaction model where teachers and students exchange ideas to generate new knowledge, share the role of learner and focus on the social inter-subjective nature of knowledge. The alternative to this is the comprehensive programming model where consideration of curriculum decisions occurs in terms of an overall program for students with LD as groups. Other programs, or models, include the segregation of environments (or interventions) or school clinics (Danielson and Bellamy 1989; Kerns and Rondeau 1998; Klinger 1998; Lloyd, Forness and Kavale 1998).

The literature contains examples of early models of learning with the assistance of ICT such as computer assisted instruction (CAI), computer based learning (CBL), and computer based training (CBT) that were used with some success with LD students. Torgesen and Young (1983), Poon and Head (1985), Schmidt et al. (1986), and Wood and Stewart (1987) reported on studies that were carried out with microcomputer programs in literacy and numeracy to develop skills with LD students. Computer managed instruction (CMI) was also used to support teaching in general. In addition to these approaches, games were also used to develop and consolidate reading and spelling skills. The educational needs of LD students were considered and Torgesen and Young (1983) had established two important principles which were adopted in the design of software programs for LD students. These were referred to respectively as the:

1. Principle of uniqueness, and the

2. Principle of educational necessity.

The former used tasks or methods for motivation, whilst the latter focused on critical problems with LD students. Most efforts were placed on the development and testing of the software to support the development of more adaptive skills. Yamamoto and Miya (1999) used computer-based teaching with autistic children to develop their language skills, Johnson (1998) used CAI to develop vocabulary skills with LD students and Stevens and Edward (1991) used microcomputer time delay and CAI to teach spelling to LD students. Clearly the early studies were limited by both hardware and also software, and they weren't very efficient, even though they provided support to the teaching of these students.

Theories developed by Bloom et al. (1956) and Gardner (1993) also have a direct application to strategies for teaching and learning with the Internet. Bloom's taxonomy of learning domains for:

- Cognitive learning - demonstrated by knowledge recall and intellectual skills

- Psychomotor learning - physical skills, coordination, dexterity.

- Affective learning - awareness, interest, attention, concern.

is well known. In a theory of multiple intelligence, Gardner has identified several different kinds of intelligence in the context of which students learn (Adam and Tatnall 2002). 
Visual/spatial

Verbal/linguistic

Mathematical/ logical

Bodily/ kinaesthetic

Musical/rhythmic

Intra-personal

Inter-personal

Naturalist

Existentialist
Visual and spatial demonstration of anything eye catching such as charts, graphs, maps, tables, illustrations, costumes, art and puzzles.

Language arts, speaking, listening, writing, reading. Best suited to traditional teaching.

Numbers, reasoning, problem solving. Suited to traditional teaching.

Activities, games, movement, hands-on tasks, building. These students can be considered 'overly active' when told to sit still.

Songs, patterns, rhythms, instruments and musical expression. Often overlooked in traditional teaching.

Their own feelings, values, ideas. These students are more reserved, but intuitive about what they learn and how it applies to them.

Other people, working in groups or with a partner. People oriented. These children are considered talkative or 'too socially outgoing'.

Outdoors, animals, field trips. Also an ability to pick up on subtle differences in meaning.

This intelligence is seen in the discipline of philosophy - where humanity stands in the big picture of existence.

\section{Recent Learning Models or Concepts}

Flexible learning is a form of learner-centred education designed to cater for individual needs in an increasingly diverse student body. It provides learners with greater flexibility in their preparation for tertiary study, teaching and learning approaches, learning pathways and points of entry and exit. Flexible learning approaches also increase learner choice in content, sequence, method, time and place of learning. Flexible learning approaches are often associated with the increased use of communication and information technologies but do not depend on technology and are unlikely to rely on online learning exclusively. Flexible learning approaches also encourage teachers to vary their response appropriately to address a student's learning request or demonstrated need.

Online learning (also known as e-learning, web-based learning or distributed learning) involves the use of communications and information technology networks, usually the Internet, to support learning. Online learning may include the provision of online learning resources, online support of student-student and student-teacher communication, online student assessment, online student learning support and online administrative services.

Online technology can make a key contribution to learner-centred flexible learning. To do so, online learning must focus on meeting learner needs to improve learning and not just on using technology to transfer information. The main intention of learner-centred flexible learning is to increase learner choice and accommodate learner diversity.

Online learning requires a simple-to-use, stable and reliable communication and information technology network. Servers and networks must be operated and maintained continuously and support must be available outside office hours. In the case of WebCT, this means that robust backup systems must be in place to ensure that WebCT is fully operational continuously.

A government project report included the study and role of educational technology in Australian schools. The project was titled 'Technology for Learning: Students with Disabilities' (Ministerial Advisory Committee: Students with Disabilities 2000). The core research questions that were investigated were: What are the current processes used by teachers to implement learning programs for students with disabilities using computer-based learning technology? What are the critical components of such processes? 
The findings of the project clearly support many researchers (Holzberg 1994) that technology by itself does not make a difference, however, the integration of technology or ICT with effective teaching and learning strategies does enable students to enhance their learning in a considerable manner. There are several aspects which were identified as key inhibitors in schools:

- $\quad$ staff training

- computer literate staff

- staff release time

- external disability support staff

- parents as carers

- $\quad$ rural and remote settings

- teacher attitudes to technology and ICT.

The current research examines these inhibitors or blockers closely and tries to develop strategies towards the application of a robust e-learning and technology based model in a special pilot project.

\section{Building a Learning Society}

It has been demonstrated at the state level that a key aim was to foster an education system in which ICT became part of the every day classroom. This required an education system that adequately resourced students' and teachers' ICT needs so they would maximise the benefits of ICT in all subjects. Several case studies that relate to this policy framework include: New Realities, RED LAB, and Boosting E-commerce.

\section{Virtual Communities and the Internet}

The Collins English Dictionary defines a community as 'a group of people having cultural, religious, ethnic or other characteristics in common.' A virtual community is a group of people who share a common interest or bond, but rather than meeting physically they 'form communities that cross geographical, social, cultural and economic boundaries' (Matathia $1998: 156$ ) and communicate via the Internet (Matathia 1998; Schneider and Perry 2001 :10). Rheingold (1993 :5) defines virtual communities as 'social aggregations that emerge from the Net where enough people carry on those public discussions long enough, with sufficient human feeling, to form webs of personal relationships in cyberspace'. Examples of virtual communities, using computer and modem, include the group of older people who share a common life stage, music lovers with an affection for a particular genre, and teenagers battling through 'the trials and tribulations of adolescence' (Matathia 1998 :156).

There are a number of alternative names for virtual communities such as 'communities of interest' (Hagel and Armstrong 1997) and 'Internet cultures' (Jones 1995). From an on-line marketing perspective Muniz (1997) calls them 'brand communities' and Kozinets (1998) uses the term 'virtual communities of consumption'. Barnatt (1998) suggests that there are two categories of virtual community: off-line and on-line. Both categories share common interests and bonds but on-line, Internet-based virtual communities today 'allow a wide range of global individuals to argue, share information, make friends, and undertake economic exchanges, in a flexible and socially-compelling common on-line arena' (Barnatt 1998). In contrast, members of an off-line virtual community do not communicate directly with one another but are reliant on 'broadcast' mediums such as newspapers, TV and radio to sustain their common interests or bonds.

An example of a virtual community (Lepa 2002) is the group of Australian older people who use the GreyPath Village. This provides for chat facilities, sharing a common bond of ageing (Bosler 2001). Matathia (1998:156) suggests that these on-line relationships can be every bit as strong and permanent as their 'real world' counterparts. 
The above definitions also apply to a community of special schools in the outer metropolitan area of Melbourne. The schools are keen to set up relationships involving students mainly through exchange programs, but there is growing interest to utilise ICT and the Internet. A major project will involve the schools participating in specially designed programs that will engage the students with online learning activities.

It should be mentioned here that each school has been asked by the State Government to propose its own Educational Technology plan. The proposed project will incorporate such a plan during the research data collection phase. It is hoped that the data will be useful in providing knowledge about the way technology and ICT can assist students with LD. As an extension, the study hopes to provide guidelines and directions about future career paths or options that are in accordance with government principles.

\section{Transformation of Concord School's Victorian Certificate of Applied Learning Program via Implementation of One-to-One Information and Computer Technology}

\section{Concord School, Transition Centre}

The Concord School Transition Centre caters for approximately 60 to 70 students from Years 10, 11 and 12. There are three learning programs delivered in the Transition Centre, each of which offers an applied learning curriculum. In Year 10, students complete the pre-transition learning program. This program has been specifically designed to prepare students for their post-compulsory schooling. In Years 11 and 12 there are four class groups of approximately twelve students. Students in three of the class groups complete their VCAL (Victorian Certificate of Applied Learning) award. The fourth class completes a Special Needs Learning Framework (SLNF) learning program (Concord School 2003). Both the VCAL and SNLF are completed over two years. The SNLF was developed by Transition Centre staff at Concord School to meet the needs of the high support students.

\section{The One-to-One Information and Communications Technology Initiative}

In this paper we will focus on the implementation of a One-to-One (121) Information and Communications Technology (ICT) initiative in the Transition Centre. In simple terms this will require the school to invest in a computer (lap-top or desk-top) for each student, as well as other accompanying software and hardware (including an interactive whiteboard) for VCAL students.

The 121 ICT initiative is in the initial phase of implementation. It is a direct response to a vision proposed by the teaching team in the Transition Centre (Davies and Davies 2005). The 121 ICT implementation plan was devised during discussions at a section planning day. Teachers made the decision that a significant way to improve teaching and learning practices - which assist personalised learning (Hargreaves 2004), would be via establishing 121 ICT learning classrooms. In this vision all the VCAL teachers identified the need for all students to have access to a computer during all their learning time. The initial proposal will be for one classroom to act as a pilot program - with other classes accessing 121 ICT over the following four year planning cycle. This would form a core part of the Transition Centre's Strategic Plan for 2006 to 2010.

The Blueprint from the Victorian Department of Education and Training (DET) for Government Schools requires the achievement of literacy and numeracy levels, participation in and outcomes from education, across the population for all Victorians from wherever and from whatever background, that has not yet been achieved anywhere in Australia and seldom elsewhere in the world (State Government of Victoria 2003 :Introduction). The 121 ICT project offers opportunities for students to use technology that will demonstrably improve their literacy output, access and exposure to technology as well as increase student engagement. Information technology is a targeted area for improvement in the Victorian Government's Flagship One strategy as part of its Blueprint for Government Schools (State 
Government of Victoria 2003). The rationale that was be presented to Concord School Council reflected these ideas that were the result of the initial visioning process, as well as further team workshops amongst teachers (Harris 2005).

\section{Charter Priorities and the 121 Initiative}

121 ICT links directly with the provision and assessment in the VCAL program. One of the charter priorities is to improve access to the VCAL program for students in the Transition Section. Improving access means enabling more of the students to meet the requirements of more units of work, and thus, attain a VCAL award. The VCAL students have demonstrated that they experience learning success and engagement when they are given access to technology. It is the lack of on-going access to such technology that is a primary area of concern and must be addressed. Teacher observation regarding student behaviour and students' expressed learning preferences over the past twelve months have significantly raised the teams' awareness regarding students' need to access ICT. This need has now reached a tipping point (Gladwell 2001) and may lead to significant and sustained transformation in student learning (Caldwell 2005).

121 ICT will improve the delivery of the Victorian Certificate of Applied Learning Program, and thus support improved student learning. At Concord School a Foundation Level VCAL Program is offered over two years. The students complete a range of VCAL and Certificate of Transition Education (CTE) units as well as TAFE (Technical and Further Education) course work, as part of their VCAL Program.. The VCAL Program at Concord School will undergo significant change in 2006. The Victorian Qualifications Authority (VQA) has approved the introduction of new literacy and numeracy units at foundation level. Presently only four VCAL units are offered at Concord School whereas next year up to ten will be offered - including three Industry Specific Skills units, which are Vocational Education and Training (VET) certificates. For each VCAL unit of work a student completes, the VQA require the development of portfolios of evidence for units of study. Presently the VCAL students at Concord School develop electronic portfolios and it is hoped that access to 121 ICT will further support the students' skills and abilities in this area. The culture of continuous improvement in DET policy promotes change as part of Victorian State School cultural practice (State Government of Victoria 2003). The driving force behind this change is not to continuously re-invent education but to build upon existing best practice (State Government of Victoria 2003). The Transition Team believe that the integration of a 121 ICT program reflects the Schools' commitment to a culture of continuous improvement.

The implementation of 121 ICT classroom environments will also require the development of a new shared curriculum and a new pedagogical focus (Davies and Davies 2005). This will necessitate moving away from autonomous teaching practices and incorporating new approaches to teaching (Southworth 2005), including a teacher commitment to personalised learning for students (where learning experiences are student directed). Sustained transformation will require that staff commit to undertaking the necessary professional development required in order to prepare for these changes (Southworth 2005). Teachers will also be required to share information and teaching resources in a professional learning team and on a school based VCAL resource bank (Hargreaves 2005). There has also been discussion pertaining to sharing the professional learning with the wider education community (the method by which this will occur is still being negotiated).

\section{Inclusion of Key Stakeholder Groups}

It is essential to include the students themselves in the change process being embarked upon (Davies and Davies 2005). As the driving force of current change initiatives are concerned with improving student learning outcomes (State Government of Victoria 2003) it is of critical importance that students have a part in driving that change. Each of the key stakeholder groups have been invited into the change process via questionnaires, discussion groups, meetings and sharing of information (via the school newsletter for instance). This has encouraged all members of the school community to share their ideas 
about how to maximise the use of a 121 ICT environment by, for instance, asking parents what their needs will be, inviting students to express their ideas and linking teachers to create a shared process (Harris 2005). The Leadership team at Concord are supporting staff by providing professional training not only in technology skills, but also in pedagogy.

Many partnerships need to be established between members of the Concord learning community in order for the 121 ICT initiative to be successful. The nature of the partnerships will vary. Some partnerships will be defined by fiscal relationships, others by ensuring clear and constant communication between stakeholder groups. Of particular importance will be the links between technology staff and VCAL teaching staff. Fundamental to the initiative will be expert technological support to assist teachers as they learn new skills and teaching processes. Technological expertise will also be required to maximise functionality of any new technology implemented.

\section{A Virtual Community of Special Schools}

The aim of the research project is to set up an environment using the Internet and ICT to enable the communication of students through videos, email, and other suitable programs for students of peer group ability and function. There has been a growing interest to set up a virtual community between the schools and expand this further to include an overseas school from Hong Kong. There has also been interest in involving TAFE, the Royal Children's Hospital (RCH) Educational Institute and some other organisations.

The research will involve a pilot study of a group of students in the upper secondary (Transition) group in outer metropolitan area of Melbourne. The pilot study will focus on curriculum design and the issues associated with this for a special 'thinking curriculum'. The school population is approximately 250 , which includes students from lower primary to upper secondary age groups. The school caters for students with mild disabilities and it has a technology-based focus. This is recognised as one of the strengths of the school curriculum. The research goal is to find out how technology can be used to establish and/or increase engagement (and thus improve student learning outcomes) for special needs students. The desired outcome is to develop a plausible model of technology implementation (hardware and software) to achieve the desired result of increased student engagement and improved learning outcomes. This involves:

- The study of learning models and understanding how kids learn as well as the study of teacher paradigms.

- Establishing a technology skills matrix and developing an appropriate teaching/learning model that marries with the skills matrix. The matrix will be developed in two parts thinking/learning skills and technology skills. The skills matrix will include such things as problem solving and communication skills (for example). The study will analyse what skills might be included in the skills matrix - in reference to 'learning to learn' / 'thinking curriculum' pedagogy.

- The model with then be tested via its application in a learning environment and applying appropriate measures. This involves setting criteria for measurement. This part of his study will examine whether the application of technology leads to students meeting the expected learning outcomes.

The overarching questions are to what extent can technology be integrated into the curriculum? How can we harness technology to enhance learning? How can technology support our VCAL and CTE module learning outcomes? How can we increase student participation in 'the 'virtual (global) community'? The role of the teacher will be as an 'action learner', to become skilled in the use and application of ITC and then to train other teachers. 


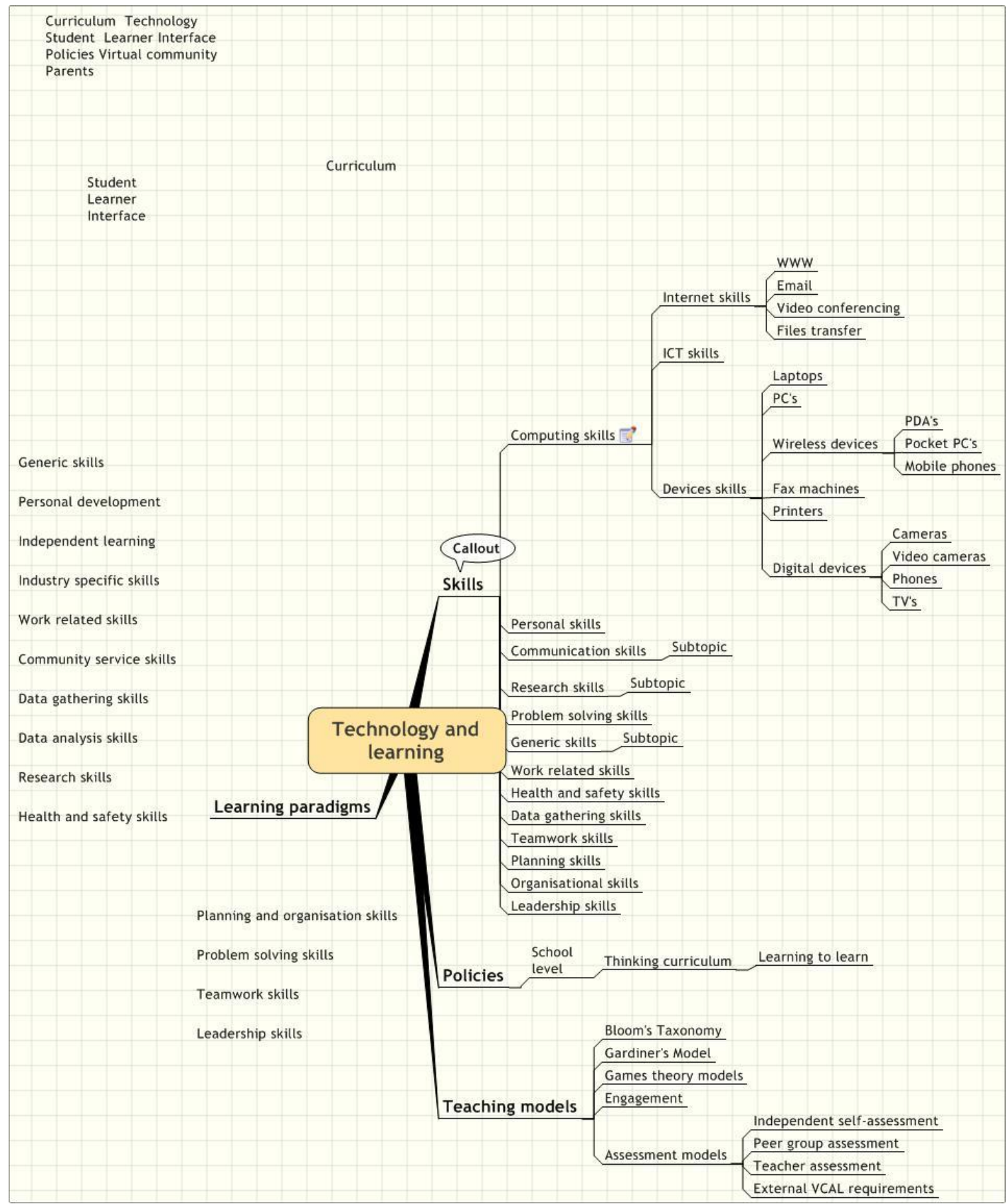

Figure 5: Mind Map of teaching, learning, skills and technology

\section{Methodology and Data Collection}

The project will require establishment of a pilot 121 Learning Classroom and the provision of a laptop computer to each student and teacher and a SmartBoard to the pilot class. It will be necessary to consult with technology staff regarding purchase, installation and training of teachers and students in the use of this new technology. The 121 Learning would require a partnership between teaching and technology staff, with technology staff advising and assisting teachers with the integration of ICT into a 121 Learning Environment involving fully integrating technology. Student progress will be tracked via the production of technology-based work. 
The following data will be tracked to demonstrate that investment in establishing a 121 Learning Environments has contributed to improved student learning outcomes:

- Number of students attaining VCAL Certificate, completing unit requirements

- Student self assessment - reporting on use of ICT in own learning

- Teacher assessment - running records of tasks completed by individuals and class, ICT employed by teacher and students

- Tracking Internet sites accessed

- Parent and student opinion surveys - internal and external (benchmarks)

- Engagement - tracking incident reports, level of behavioural issues, absentee rates

- Development of student digital portfolios for demonstration night.

- Demonstration classes/open classroom for members of the school community to see 121 in action.

The anticipated outcomes are: increased student engagement, increased opportunities for students to participate in learning that contributes to competency based assessment, increased opportunities for students to produce high quality work independently, completion of core work on line, and the capacity to complete required assessment tasks as defined by the Victorian Qualifications Authority in respect to VCAL Certification.

\section{Conclusion}

The 'thinking curriculum' or 'learning to learn' pedagogy requires students learning programs to be personalised, meaning that student learning is student-driven. Learning to learn and understanding how one learns is a critical part of personalised learning pedagogy. ICT offers students an increased capacity to construct their own learning experiences. Technology can assist students with LD and research with the virtual community will demonstrate how the relationships are fostered through the use of ICT and Internet-based technologies. The outcome of the research will be a suitable learning model that incorporates technology and human factors in the development of skills and knowledge of students with LD. This research will add to work carried out earlier in the national project in 2000 for this important and vital virtual community.

\section{References}

ABS (1996). Commercial Training Providers, Australia - 1994. Canberra, Australian Bureau of Statistics: Catalogue No. 6352.0.

ABS (1997). Education and Training Experience Australia. Canberra, Australian Bureau of Statistics: Catalogue No. 6278.0.

ACLD (1986). 'Specific Learning Disabilities.' Association for Children with Learning Disabilities (ACLD) Newsbrief 159: 15-16.

Adam, T., Rigoni, A. and Tatnall, A. (2005). The Application of ICT in the Development of a Thinking Curriculum: a Pilot Project for Students with Special Needs. $1^{\text {st }}$ Victoria University Business Research Conference.

Adam, T. and Tatnall, A. (2002). Using Web-Based Technologies to Enhance the Learning of Students with Learning Disabilities who Live in Regional Areas. IT in Regional Areas (ITiRA2002), Rockhampton, Australia, Central Queensland University.

Adam, T. and Tatnall, A. (2003). Using Information and Communication Technologies to Enhance the Learning Outcomes of a Virtual Community of Students with Learning Disabilities. ACIS 2003, Perth, ACIS. 
Agran, M. (1977). 'Teaching Self-Instructional Skills to Persons With Mental Retardation: A Descriptive and Experimental Analysis.' Education and Training of the Mentally Retarded 21: 273281.

Barnatt, C. (1998). 'Virtual communities and financial services - on-line business potentials and strategic choice.' International Journal of Bank Marketing 16(4).

Bloom, B. S., Englehart, M. D., Furst, E. J., Hill, W., H. and Krathwohl, D., R. (1956). Taxonomy of Educational Objectives. Handbook 1: Cognitive Domain. Ann Arbor, Michigan, Longmans, Green and Co Ltd.

Bosler, N. (2001). Communication, E-Commerce and Older People. E-Commerce, Electronic Banking and Older People, Melbourne, Unpublished Seminar Presentation.

Browder, D. M. and Yan, P. X. (1998). 'Meta-analysis and review of sight word research and its implications for teaching functional reading to individuals with moderate and severe disabilities.' Journal of Special Education 32(3): 130-154.

Bulgren, J. (1998). 'Effectiveness of a concept teaching routine in enhancing the performance of LD students in secondary-level mainstream classes.' Learning Disability Quarterly 11.

Caldwell, B. (2005). Global Transformations. Date accessed: November 2005, http://www.educationaltransformations.com.au/publications.php

Concord School (2003). Special Needs Learning Framework. Bundoora, Victoria, Concord School.

Danielson, L. C. and Bellamy, G. T. (1989). 'State variation placement of children with handicaps in segregated environments.' Exceptional Children 55(5): 448-455.

Davies, B. and Davies, B. J. (2005). Strategic Leadership, in The Essentials Of School Leadership. London, Paul Chapman Publishing and Corwin Press.

Dempsey, J. (1993). 'Since Malone's Theory of Intrinsically Motivating Instruction: What's the Score in The Gaming Literature?' Journal of Educational Technology Systems 22(2): 173-183.

Deshler, D. and Ellis, E. (1996). Teaching Adolescents with Learning Disabilities: Strategies and Methods, Love Publishing.

Detterman, D. K. and Thompson, L. A. (1997). 'What is so Special about Special Education?' American Psychologist 52(October): 63-82.

Dillon, R. (1985). Individual Differences in Cognition, Vol 2, Academic Press.

Fernell, E. (1996). Mild Mental retardation in school children in a Swedish suburban municipality: prevalence and diagnostic aspects, Scandinavian University Press.

Fuchs, L. S. (1996). Models of classroom Instruction: Implications for students with learning disabilities. Research on Classroom Ecologies. B., K. and Speece D., Lawrence Erbaum Associates.

Gardner, H. (1993). Multiple Intelligences: The Theory in Practice. New York, Basic.

Gladwell, M. (2001). The Tipping Point. London, Abacus.

Hagel, J. and Armstrong, A. (1997). Net Gain: Expanding Markets through Virtual Communities. Harvard Business School. Boston, MA., Harvard.

Hargreaves, A. (2005). Sustainable Leadership, in The Essentials Of School Leadership, Paul Chapman Publishing \& Corwin Press.

Hargreaves, D. (2004). Personalising Learning: The Nine Gateways. London, Specialist Schools Trust.

Harris, A. (2005). Distributed Leadership, in The Essentials Of School Leadership. London, Paul Chapman Publishing and Corwin Press.

Holzberg, C. (1994). 'Technology in Special Education.' Technology in Learning(April): 21.

IDEA (1997). Individuals with Disabilities Education Act, United States. 20 USC 1401 [26].

Johnson, G., Gersten, R. and Carmine, D. (1998). 'Effects of Instructional Design Variables on Vocabulary acquisition of LD students: A Study of computer-assisted Instruction.' Journal of Learning Disabilities 20(4).

Johnson, G. M. (1998). Students at Risk: Towards a New Paradigm of Mild Educational Disabilities, Sage Publication. 
Jones, S. (1995). Understanding community in the information age. Cybersociety: Computer-mediated Communication and Community. Jones, G. Thousand Oaks, CA, Sage: 10-35.

Keogh, B. and Speece, D. (1996). Research on Classroom Ecologies: Implications for Inclusion of Children with Learning Disabilities, Lawrence Erlbaum Associates.

Kerns, K. A. and Rondeau, L. A. (1998). 'Development of a continuous performance test for preschool children.' Journal of Attention Disorders 2.

Kircaali-Iftar, G., Birkan, B. and Uysal, A. (1998). 'Comparing the Effects of Structural and Natural language Use during direct Instruction with Children with Mental Retardation.' Education and Training in Mental Retardation and Developmental Disabilities 33(4): 375-385.

Kirk, S. A. (1962). Educating exceptional children. Boston, Houghton Mifflin.

Klinger, J. K. (1998). 'Outcomes for Students With and Without Learning Disabilities in Inclusive Classrooms.' Learning Disabilities Research \& Practice 13(3): 153-161.

Kozinets, R. (1998). On netnography. Initial reflections on consumer research investigations of cyberculture. Advances in Consumer Research. Alba, J. and Hutchinson W. Provo, UT, Association for Consumer Research: 366-371.

Lepa, J. (2002). Internet Information Services for Older Australian People. Pan-Pacific Conference XIX 'e-Globalization and the Pacific Age', Bangkok, Thailand.

Lloyd, J. W., Forness, S. R. and Kavale, K. A. (1998). 'Some Methods are More Effective than Others.' Intervention In School And Clinic 33(4): 195-200.

Matathia, I. S. (1998). NEXT Trends for the Future. Australia, McMillan.

Mather, N. and Roberts, R. (1994). 'Learning disabilities: A field in danger of extinction?' Learning Disabilities Research and Practice 9: 48-59.

MCEETYA (1997). National Schools Statistics Collection 1989-97.

McIntosh, R. (1993). 'Observations of Students with Learning Disabilities in General Educational Classrooms.' Exceptional Children 60.

Mercer, C. D. and Mercer, A. R. (1981). Teaching students with learning problems. Columbus, OH., Merill.

Ministerial Advisory Committee: Students with Disabilities (2000). Technology for Learning: Students with Disabilities. Canberra, Commonwealth of Australia.

Morrison, G. M., Macmillan, D. L. and Kavale, K. (1985). 'System Identification of Learning Disabled Children: Implications for Research Sampling.' Learning Disability Quarterly 8: 1-10.

Muniz, A. M. (1997). Brand community and the negotiation of brand meaning. Advances in Consumer Research. Brucks, M. and MacInnis D. J. Provo, UT, Association for Consumer Research: 308309.

NJCLD (1994). Learning disabilities: Issues on definition revised. Collective Perspectives on Issues Affecting Learning Disabilities. Austin, TX, PRO-ED: 61-66.

Pillay, H. (2000). 'Cognition and Recreational Computer Games: Implications for Educational Technology.' Journal of Research on Computing in Education 32(1): 32-41.

Poon, P. and Head, P. (1985). Computers Assisting People. 1st Pan Pacific Computer Conference, Melbourne, Australian Computer Society.

Quinn, C. N. (1996). 'Designing an Instructional Game: Reflections for Quest on Independence.' Journal of Education and Information Technologies. 1(1): 251-269.

Rheingold, H. (1993). The Virtual Community: Homesteading on the Electronic Frontier. New York, Harper-Collins.

Schmidt, M., Weinstein, T., Niemic, R. and Walberg, H. J. (1986). 'Computer-Assisted Instruction with Exceptional Children.' The Journal of Special Education 19(4): 493-501.

Schneider, G. P. and Perry, J. T. (2001). Electronic Commerce. Boston, Course Technology.

Schunck, L. G. and Nielsson, L. (2001). Varying Learning Paradigms. Web publication, Date accessed: June 2003, www.fcfu.dk/artikel/paradigm.htm

Southworth, G. (2005). Learning-Centred Leadership, in The Essentials Of School Leadership. London, Paul Chapman Publishing and Corwin Press. 
State Government of Victoria (2003). Blueprint for Government Schools. Melbourne, State Government of Victoria.

Stevens, K. B. and Edwards, A. (1991). 'Teaching Spelling with a Microcomputer time delay and computer -assisted instruction.' Journal of Applied Behaviour Analysis.

Swanson, L. (1999). 'Cognitive processing Deficits in poor readers with symptoms of reading disabilities: More alike than different.' Journal of Educational Psychology 91(2.): 321-333.

Torgesen, K. J. and Young, K. A. (1983). 'Priorities For The Use of Microcomputers with Learning Disabled Children.' Journal of Learning Disabilities 16(4).

Van Luit, J. E. H. and Naglieri, J. A. (1999). 'Effectiveness of the MASTER program for teaching special children.' Journal of Learning Disabilities 32(2): 98-108.

Wang, M., Reynolds, M. and Walberg, H. J. (1987). Handbook of Special Education Research Practice, Vol 1, Pergammon Press.

Wood, L. E. and Stewart, P. W. (1987). 'Improvement of Practical Reasoning Skills with a Computer Game.' Journal of Computer -Based Instruction 14(2): 49-53.

Yamamoto, J. and Miya, T. (1999). 'Acquisition and Transfer of Sentence Construction in Autistic Students: Analysis by Computer-Based Teaching.' Research in Developmental Disabilities 20(5): 355-377.

Zammit, S. A., Meiers, M. and Frigo, T. (1999). Assessment and Reporting of Student Achievement for Students with Specific Educational Needs against Literacy and Numeracy Benchmarks. Melbourne, ACER. 
